\title{
PENGARUH PENGGUNAAN METODE DRILL TERHADAP KETERAMPILAN MENULIS KARANGAN NARASI SISWA KELAS X SMAN 1 KECAMATAN PAYAKUMBUH
}

\author{
Sri Mures Walef ${ }^{1}$ \\ STKIP Abdi Pendidikan Payakumbuh \\ *srimureswalef1983@gmail.com
}

\begin{abstract}
ABSTRAK
Jenis penelitian ini adalah penelitian kuantitatif dengan menggunakan metode eksperimen. Dalam penelitian ini digunakan dua kelas, yaitu kelas eksperimen dan kelas kontrol. Analisis data menunjukkan bahwa metode drill mempengaruhi pembelajaran penulisan naratif pada keterampilan menulis bahasa Indonesia di kelas eksperimen. Hal ini dibuktikan dengan kenaikan nilai siswa, yang pada saat prenting rata-rata/ mean adalah 68,16 . Setelah metode kolaboratif diterapkan dalam proses belajar di kelas ini, hasil belajar siswa meningkat pada saat pascatest dengan nilai rata-rata 82,60. Metode konvensional juga berpengaruh dalam pembelajaran menulis naratif esai tentang subjek bahasa Indonesia di kelas kontrol. Kenaikan nilai siswa, waktu rata-rata nilai mean adalah 67,72. Setelah metode konvensional diterapkan dalam proses belajar di kelas ini, hasil belajar siswa meningkat pada saat pascates dengan nilai rata-rata 71.40. Berdasarkan hasil pengujian, disimpulkan bahwa ada perbedaan yang signifikan antara hasil narasi yang dipelajari. menulis antara metode drill dan metode konvensional.
\end{abstract}

Kata kunci: metode drill, metode konvensiobalm menulis karangan narasi

\section{PENDAHULUAN}

$\mathrm{P}$ endidikan merupakan tujuan untuk membimbing siswa agar memiliki pengetahuan, keterampilan, dan sikap positif yang akan digunakan untuk menjalani kehidupan. Sehingga, suatu pendidikan dapat dikatakan berhasil apabila siswa memperoleh perubahan kearah yang lebih baik dalam perkembangan pengetahuan, penguasaan keterampilan dan perubahan sikap positif dalam kehidupannya. Salah satu keterampilan yang harus dikuasai siswa adalah keterampilan dalam berbahasa yang akan sangat berguna dalam hal berkomunikasi. Dalam mata pelajaran bahasa Indonesia siswa akan belajar empat keterampilan 
dasar berbahasa yaitu, keterampilan membaca, keterampilan menulis, keterampilan mendengarkan, keterampilan berbicara. Keempat keterampilan berbahasa di atas memiliki tantangan yang berbeda bagi guru untuk mengajarkannya kepada siswa.

Berdasarkan fakta yang ada dilapangan, pembelajaran keterampilan menulis ini masih dikatakan kurang dan kemampuan siswa untuk menulis juga masih rendah. Keterampilan menulis ini menjadi keterampilan berbahasa yang paling akhir dikuasai siswa setelah keterampilan mendengarkan berbicara, membaca. Hasil observasi yang dilakukan terhadap siswa dan guru dapat diketahui bahwa kesulitan yang dialami dalam menulis adalah sulitnya menemukan ide-ide untuk diceritakan dalam bahasa tulis yang runtut. Hal ini disebabkan cara guru menyampaikan pembelajaran kurang inovatif dan cenderung hanya menyampaikan teori yang perlu diketahui siswa tanpa latihan dan praktik yang memadai.

Dari hasil pembelajaran yang guru lakukan selama ini, keterampilan menulis siswa memang masih rendah, banyak yang belum mencapai KKM, sedangkan KKM yang harus dicapai 75 .

Alasan yang sering didengar guru dari siswa ternyata memang sulitnya menemukan ide untuk dikembangkan menjadi cerita. Mungkin karena guru masih menggunakan metode konvensional (ceramah) sehingga siswa belum mampu mengoptimalkan kemampuannya. Hal inilah yang menyebabkan perlunya mengambil tindakan untuk meningkatkan keterampilan menulis karangan narasi siswa. Salah satu metode yang dapat digunakan adalah metode Drill. Metode drill/atihan. Metode ini metuntut siswa untuk aktif dalam menulis karangan narasi.
Metode ini lebih berpusat pada latihanlatihan berulang agar para siswa lebih memahami materi yang sudah diajarkan. Sebagian besar siswa tidak sepenuhnya paham dengan materi yang telah diberikan guru terutama pada mata pelajaran karangan narasi, disinilah siswa akan mengalami kebingungan menyusun katakata dalam sebuah karangan. Oleh karena itu dengan menggunakan metode drill atau latihan diharapkan pemahaman siswa yang disampaikan akan lebih baik lagi, sehingga diharapkan dengan menggunakan metode drill akan memacu motivasi belajar siswa yang akhirnya berdampak pada hasil belajar yang maksimal. Dengan menerapkan metode drill/latihan ini, penulis berharap hasil belajar siswa menjadi maksimal sehingga hasil belajar siswa dalam pelajara Bahasa Indonesia bisa meningkat.

Dengan latar belakang masalah di atas, penulis merasa tertarik dan berkeinginan untuk melakukan penelitian di SMA Negeri 1 Kecamatan Payakumbuh dengan judul“ Pengaruh Penggunaan Metode Drill Terhadap Keterampilan Menulis Karangan Narasi Siswa Kelas X SMA Negeri 1 Kecamatan Payakumbuh". Alasan penulis memilih mengadakan penelitian di atas karena sekolah tersebut merupakan sekolah yang cukup berprestasi dan ingin melihat adakah pengaruh metode pembelajaran terhadap peningkatan hasil belajar siswa.

Menurut Semi (2007:53) narasi adalah tulisan yang tujuannya menceritakan kronologis peristiwa kehidupan manusia.Sedangkan menurut Nurudin (2010:71) narasi adalah bentuktulisan yang berusaha menciptakan, mengisahkan, merangkaikan tindak-tanduk perbuatan manusia dalam sebuah peristiwa secara kronologis atau yang berlangsung dalam suatu kesatuan waktu tertentu.

Menurut Semi (2007:53) ciri-ciri narasi yaitu: (a) Tulisan itu berisi cerita 
tentang kehidupan manusia. (b) Peristiwa kehidupan manusia yang diceritakan itu boleh merupakan kehidupan nyata, imajinasi, dan boleh gabungan keduanya. (c) Cerita itu memiliki nilai keindahan, baik keindahan isinya maupun penyajiannya. (d) Di dalam peristiwa itu ada konflik, yaitu pertentangan kepentingan, kemelut, atau kesenjangan antara harapan dan kenyataan. Tanpa konflik cerita tidak menarik. (e) Di dalamnya seringkali terdapat dialog untuk menghidupkan cerita. (f) Tulisan disajikan dengan menggunakan cara kronologis.

Menurut Semi (2007:54) narasi terbagi dua jenis yaitu: (1) narasi artistik adalah narasi yang berbentuk karya sastra yang enak dibaca, seperti karya novel, atau cerita pendek. (2) narasi ekspositorik adalah narasi yang menceritakan tentang kehidupan seseorang yang penuh suka duka, misalnya peristiwa kecelakaan atau bencana alam.

Menurut Nurudin (2007:72) narasi terbagi dua yaitu narasi ekspositoris dan narasi sugestif. Narasi ekspositoris yaitu bertujuan untuk memberikan informasi pada pembaca agar pengetahuannya bertambah luas. Sedangkan narasi sugestif bertujuan untuk menimbulkan khayal atau mampu menyampaikan makna kepada pembaca melalui daya khayalnya.

Menurut Roestiyah (2008:125) teknik drill adalah suatu teknik yang dapat diartikan sebagai suatu cara mengajar dimana siswa melakukan kegiatan-kegiatan latihan, agar siswa memiliki ketangkasan atau keterampilan yang lebih tinggi dari apa yang telah dipelajari. Menurut Sudjana (2009:86) metode latihan atau drill pada umumnya digunakan untuk memperoleh suatu ketangkasan atau

Keterampilan dari apa yang telah dipelajari.

Menurut KBBI (2003 : 592)

konvensional adalah tradisional. Jadi yang dimaksud metode konvensional adalah metode dalam proses belajar mengajar yang menerapkan cara-cara terdahulu. Guru bertindak sebagai penyampai materi dan siswa hanya sebagai objek dalam pembelajaran. Menurut Djamarah (1996), metode konvensional adalah metode pembelajaran tradisional atau disebut juga dengan metode ceramah.

\section{METODE PENELITIAN}

$\mathbf{J}$ enis penelitian ini adalah penelitian kuantitatif dengan menggunakan metode eksperimen. Menurut Arikunto, (2006: 12) bahwa penelitian kuantitatif penelitian yang banyak menuntut menggunakan angkaangka, mulai dari pengumpulan data sampai laporannya. Metode penelitian ini merupakan metode penelitian eksperimen. Yusuf (2013:76) metode eksperimen merupakan satu-satunya tipe penelitian yang lebih akurat atau teliti dibandingkan dengan penelitian yang lain, dalam menentukan relasi hubungan sebab akibat. Penelitian eksperimen merupakan satu penyelidikan yang dirancang sedemikian rupa sehingga fenomena atau kejadian itu dapat disosialisasi dari pengaruh-pengaruh lain.

Penelitian ini menggunakan dua kelompok sampel yaitu eksperimen dan kelas control. Kelas eksperimen menggunakan metode drill, sedangkan kelas control tidak menggunakan metode drill. Pelaksanaan penelitian terhadap kedua kelas sampel diberi perlakuan yang berbeda. Kemudian dicari perbedaan rata- 
rata pengukuran dari kedua sampel diberi perlakuan dan perbedaan ini disebabkan oleh perlakuan. Berdasarkan uraian diatas maka desain penelitian yang digunakan adalah The Randomized

Posttes Only Control Group (Yusuf, 2013:191), dapat digambarkan sebagai berikut:

Pada kelas eksperimen yang diberikan adalah perlakuan dan posstest sedangkan untuk kelas control hanya posttest saja (Yusuf, 2003:191).

Keterangan:

$\mathrm{X}$ : perlakuan yang diberikan pada kelas eksperimen yaitu penggunaan metode drill.

Tempat penelitian dan sumber data penelitian adalah SMA Negeri 1 Kecamatan Payakumbuh.Penelitian diadakan pada semester ganjil tahun pelajaran 2016/2017.

\section{HASIL DAN PEMBAHASAN}

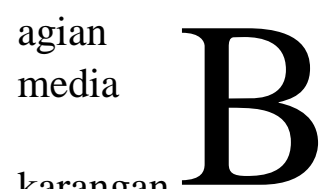

Metode drill merupakan yang digunakan dalam keterampilan menulis narasi dengan tema pangalaman berlibur di kelas eksperimen. Sebelum guru dan siswa melaksanakan kegiatan keterampilan menulis karangan narasi dengan metode drill, guru menjelaskan kegiatan pembelajaran menulis narasi yang akan dilakukan siswa. Hal ini supaya siswa paham dengan metode yang digunakan guru dalam mengajar. Berikut ini langkah-langkah praktis yang dilakukan oleh guru dan siswa setelah prates dan pascates.

\section{Pengaruh Metode Drill pada Kelas Eksperimen}

Berdasarkan hasil dari prates dan

pascates, maka didapat perhitungan statistik pada kelas eksperimen sebagai berikut:

Tabel 1. Data Statistik Kelas Eksperimen

\begin{tabular}{|l|c|c|}
\hline \multicolumn{1}{|c|}{ Tes } & $\boldsymbol{\Sigma}$ & $\bar{X}$ \\
\hline Prates & 1704 & 68.16 \\
\hline Pascates & 2065 & 82.60 \\
\hline
\end{tabular}

Dari hasil tabel di atas dapat disimpulkan bahwa adanya pengaruh metode drill dalam pembelajaran menulis karangan narasi pada mata pelajaran bahasa Indonesia di kelas eksperimen. Hal ini dibuktikan dengan adanya peningkatan nilai siswa, yang mana pada waktu prates total nilai $(\Sigma) 1704$ dan nilai rata-rata/mean $(\bar{X})$ adalah 68.16. Setelah diterapkan metode drill dalam proses belajar di kelas ini, didapat peningkatan hasil pembelajaran siswa pada waktu pascates dengan total nilai $(\Sigma) 2065$ dan nilai rata-rata $(\bar{X}) 82.60$.

\section{Pengaruh Metode konvensional pada Kelas Kontrol}

Pada kelas kontrol, siswa diajar dengan menggunakan metode konvensional. Perhitungan statistik yang didapat setelah pascates pada kelas kontrol adalah sebagai berikut:

\section{Tabel 2. Data Statistik Kelas kontrol}

\begin{tabular}{|l|c|c|}
\hline \multicolumn{1}{|c|}{ Tes } & $\boldsymbol{\Sigma}$ & $\bar{X}$ \\
\hline Prates & 1693 & 67.72 \\
\hline Pascates & 1785 & 71.40 \\
\hline
\end{tabular}

Dari hasil tabel di atas dapat disimpulkan bahwa adanya pengaruh metode konvensional dalam pembelajaran menulis karangan narasi pada mata pelajaran bahasa Indonesia di kelas kontrol. Hal ini dibuktikan dengan adanya peningkatan nilai siswa, yang mana pada waktu prates total nilai $(\Sigma) 1693$ dan nilai 
Sri Mures Walef: Pengaruh Penggunaan Metode Drill Terhadap Keterampilan Menulis Karangan Narasi Siswa kelas X SMA N 1 Kecamatan Payakumbuh

Website : https://jurnal.umj.ac.id/index.php/penaliterasiEmail : penaliterasi@umj.ac.id rata-rata/mean $(\bar{X})$ adalah 67.72 . Setelah diterapkan metode konvensional datam proses belajar di kelas ini, didapat peningkatan hasil pembelajaran siswa pada waktu pascates dengan total nilai $(\Sigma) 1785$ dan nilai rata-rata $(\bar{X}) 71.40$.

3. Perbedaan Signifikan Antara Hasil Menulis Karangan Narasi Dengan Menggunakan Metode Drill dan Metode Konvensional

Untuk melihat perbedaan signifikan antara hasil pembelajaran menulis karangan narasi dengan metode drill dan metode konvensional, penulis melakukan perbandingan nilai pascates antara kedua kelas:

Tabel 3. Perbandingan Nilai Pascates

\begin{tabular}{|c|c|c|c|c|c|}
\hline \multicolumn{3}{|c|}{$\begin{array}{c}\text { Kelas } \\
\text { Eksperimen }\end{array}$} & \multicolumn{3}{|c|}{$\begin{array}{c}\text { Kelas } \\
\text { Eksperimen } \\
\text { II }\end{array}$} \\
\hline $\begin{array}{c}\text { Jum } \\
\text { lah } \\
\text { Sko } \\
\text { r }\end{array}$ & $\mathrm{N}$ & $\bar{X}$ & $\begin{array}{l}\text { Juml } \\
\text { ah } \\
\text { Skor }\end{array}$ & $\mathrm{N}$ & $\bar{X}$ \\
\hline $\begin{array}{c}206 \\
5\end{array}$ & 25 & $\begin{array}{c}82.6 \\
0\end{array}$ & 1785 & $\begin{array}{l}2 \\
5\end{array}$ & $\begin{array}{l}71 \\
40\end{array}$ \\
\hline
\end{tabular}

Dari tabel di atas dapat dilihat ratarata kelas eksperimen (82.60) lebih besar dibanding kelas kontrol (71.40). Hal ini menunjukkan bahwa adanya perbedaan yang signifikan antara hasil kemampuan menulis karangan narasi siswa dengan menggunakan metode drill dibanding penggunaan metode konvensional. Dapat disimpulkan bahwa dalam penelitian ini penggunaan metode drill lebih efektif dari pada penggunaan metode konvensional.

Maka data tersebut dianalisa dengan menggunakan tiga pengujian yaitu, uji normalitas, uji homogenitas, uji t (t-test). Pengujian ini pada akhirnya berguna untuk menguji hipotesis mana yang akan diterima. Berikut ini adalah penjelasan dari tiap pengujian tersebut:

\section{Uji Normalitas}

Uji normalitas data dilakukan untuk menguji apakah data yang diteliti berdistribusi normal atau tidak. Untuk menganalisa datanya digunakan rumus $\mathrm{Uji}$ Liliefors. Pengujian ini dilakukan pada kedua kelas: kelas eksperimen dan kelas kontrol, dan data yang digunakan adalah data dari hasil pascates. Data tersebut disimbolkan dengan $X_{i}$, kemudian ditranformasikan dalam nilai $\mathrm{Zi}$ dari angka ke notasi pada distribusi normal dengan menggunakan $\bar{X}$ dan SD dari data. Setelah itu dihitung probabilitas komulatif normal $\left(\mathrm{F}_{(\mathrm{zi})}\right)$ dan probabilitas komulatif empirisnya $\left(\mathbf{S}_{(\mathrm{zi})}\right)$. Kemudian diuji signifikansinya dengan menghitung selisih $\left\{\mathrm{F}_{(\mathrm{zi})}-\mathrm{S}_{(\mathrm{zi})}\right\}$, dan nilai terbesarnya (Liliefors hitung $=\mathrm{L}_{0}$ ) dibandingkan dengan nilai Liliefors tabel $\left(\mathrm{L}_{\mathrm{t}}\right)$. Untuk mencari $\mathrm{L}_{\mathrm{t}}$ dalam penelitian ini digunakan derajat kepercayaan $(\mathrm{dk} / \alpha)$ 0.05.Jika nilai $\mathrm{L}_{0}<\mathrm{L}_{t}$, maka data berdistribusi normal.Namun apabila $\mathrm{L}_{0}>\mathrm{L}_{\mathrm{t}}$, maka data tidak berdistribusi normal. Hasil uji normalitas pada penelitian ini dapat dilihat pada tabel berikut:

\section{Tabel 4. Hasil Perhitungan Uji Normalitas}

\begin{tabular}{|l|c|c|}
\hline Kelas & $\begin{array}{c}\text { Eksperi } \\
\text { men }\end{array}$ & Kontrol \\
\hline $\mathrm{N}$ & 25 & 25 \\
\hline$\overline{\boldsymbol{X}}$ & 82,60 & 71.40 \\
\hline SD & 1000 & 10.85 \\
\hline $\mathbf{A}$ & 0.05 & 0.05 \\
\hline $\mathbf{L}_{\boldsymbol{o}}$ & 0.0869 & 0.0961 \\
\hline $\mathbf{L}_{\boldsymbol{t}}$ & 0.1772 & 0.1772 \\
\hline Ket & Normal & Normal \\
\hline
\end{tabular}


Tabel di atas menunjukkan bahwa pada kedua kelas nilai Lo lebih kecil dibanding nilai $\mathrm{Lt}$, ini berarti sebaran data pada hasil pembelajaran menulis karangan narasi siswa yang diajar dengan metode drill di kelas eksperimen dan metode konvensional di kelas kontrol berdistribusi normal.

\section{Uji Homogenitas}

Uji homogenitas dilakukan untuk melihat apakah data mempunyai varians yang homogen atau tidak. Pada penelitian ini, penulis menggunakan Uji Harley.Uji Harley digunakan dengan membandingkan variansi terbesar dengan variansi terkecil dari data. Kemudian hasil dari $F_{\text {hitung }}$ dibadingkan dengan hasil dari $F_{\text {tabel}}$, dengan $\mathrm{df}=\mathrm{n}-1$ dan $\mathrm{k}=2$. Maka didapat hasil sebagai berikut:

Tabel 5. Hasil Perhitungan Uji Homogenitas

\begin{tabular}{|c|c|}
\hline$S_{1}^{2}$ & 102.535 \\
\hline$S_{2}^{2}$ & 115.54 \\
\hline $\mathrm{F}_{\text {hitung }}\left(\mathrm{F}_{\mathrm{n}}\right)$ & 0.88744 \\
\hline $\mathrm{N}$ & 24 \\
\hline $\mathrm{K}$ & 2 \\
\hline $\mathrm{F}_{\text {tabel }}\left(\mathrm{F}_{\mathrm{t}}\right)$ & 3.4 \\
\hline
\end{tabular}

Dari tabel di atas dapat disimpulkan bahwa $F_{n}$ lebih kecil dari $F_{t}$ $(1.76<3.40)$. ini berarti variansi dari penelitian ini bersifat homogen.

hasil menyajikan hasil penelitian yang memuat data (dalam bentuk ringkas), analisis data dan interpretasi terhadap hasil. Hasil penelitian dapat dilengkapi dengan tabel dan grafik (gambar), dan/atau bagan. Pada bagian ini haruslah menjawab masalah atau hipotesis penelitian yang telah dirumuskan sebelumnya.

\section{Uji t (t-test)}

Uji t adalah langkah terakhir yang digunakan dalam penelitian ini. Uji $t$ digunakan untuk mencari nilai thitung yang akan dibandingkan dengan nilai $t_{\text {tabel}}$, dengan tujuan untuk menentukan hipotesis mana yang diterima.

Sebelum melakukan uji $\mathrm{t}$, penulis mancari nilai standar deviasi gabungan $\left(\mathrm{S}_{\mathrm{gab}}\right)$ terlebih dahulu dengan rumus sebagai berikut: $=\frac{\left(n_{1}-1\right) s_{1}^{2}+\left(n_{2}-1\right) s_{2}^{2}}{n_{1}+n_{2}-2}$

Setelah didapat nilai $S_{g a b}: 6.596$, maka nilai tersebut digunakan pada rumus uji $\mathrm{t}$ berikut ini $t=\frac{\bar{x}_{1}-x_{2}}{s \sqrt{\frac{1}{n_{1}}+\frac{1}{n_{2}}}}$

Dari perhitungan di atas didapat nilai thitung: 3.82092. Kemudian nilai tersebut dibandingkan dengan nilai $t_{\text {tabel }}$ untuk menentukan hipotesis mana yang akan diterima, dan pembahasan tersebut dijelaskan pada sub pokok pengujian hipotesis berikut.

\section{A. Pengujian Hipotesis}

Pengujian hipotesis dilakukan dengan membandingkan nilai prates dengan pascatest dari kelas eksperimen I. Langkah awal adalah dengan menetukan $\overline{\boldsymbol{X}}$ dan SD dari nilai skor masing-masing tes. Kemudian data tersebut digunakan untuk mencari standar deviasi gabungan $\left(\mathrm{S}_{\mathrm{gab}}\right)$. Langkah selanjutnya adalah dengan menggunakan data tersebut untuk mencari

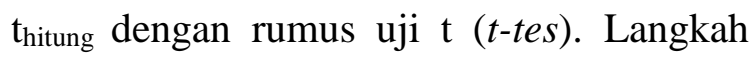
terakhir adalah dengan membandingkan

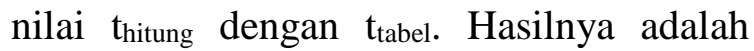
sebagai berikut: 
Sri Mures Walef: Pengaruh Penggunaan Metode Drill Terhadap Keterampilan

Menulis Karangan Narasi Siswa kelas X SMA N 1 Kecamatan Payakumbuh

Website : https://jurnal.umj.ac.id/index.php/penaliterasiEmail : penaliterasi@umj.ac.id

\section{Tabel 7. Hasil Perhitungan Uji t kontrol}

Tabel 6. Hasil Perhitungan Uji t Eksperimen

\begin{tabular}{|c|c|c|c|}
\hline $\begin{array}{c}\text { Eksperimen } \\
\text { I } \\
\end{array}$ & $\mathbf{n}$ & $\overline{\boldsymbol{X}}$ & SD \\
\hline Prates & 25 & 67.92 & $\begin{array}{l}18 . \\
60\end{array}$ \\
\hline Pascates & 25 & 82.60 & $\begin{array}{l}10 . \\
00\end{array}$ \\
\hline \multicolumn{4}{|l|}{$\begin{array}{ll}S_{\text {gab }} & : 8.238 \\
\end{array}$} \\
\hline \multicolumn{4}{|c|}{$t_{\text {hitung }}: 2.251$} \\
\hline \multicolumn{4}{|c|}{$\begin{array}{l}\mathrm{t}_{\text {tabel }}: 2.021\left(\text { dengan df: } \mathrm{n}_{1}+\mathrm{n}_{2^{-}}\right. \\
2=48 \text { dan } \alpha: 0.05)\end{array}$} \\
\hline
\end{tabular}

Dari tabel di atas dapat dilihat bahwa nilai $t_{\text {hitung }}$ lebih besar dari $t_{\text {tabel }}$ ( $t_{\text {hitung }}=2.251>t_{\text {tabel }}=2.021$ ). Ini berarti $\mathrm{H}_{\mathrm{a}}$ (hipotesis alternatif) diterima, yaitu adanya pengaruh metode drill terhadap keterampilan menulis karangan narasi siswa kelas X SMA Negeri 1 Kecamatan Payakumbuh.

Pengujian hipotesis dilakukan dengan membandingkan nilai pratest dengan pascatest dari kelas kontrol. Langkah awal adalah dengan menetukan $\overline{\boldsymbol{X}}$ dan SD dari nilai skor masing-masing tes. Kemudian data tersebut digunakan untuk mencari standar deviasi gabungan $\left(\mathrm{S}_{\mathrm{gab}}\right)$. Langkah selanjutnya adalah dengan menggunakan data tersebut untuk mencari

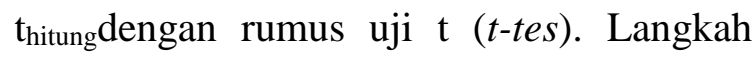
terakhir adalah dengan membandingkan nilai thitung dengan $t_{\text {tabel }}$. Hasilnya adalah sebagai berikut:

\begin{tabular}{|c|c|c|c|}
\hline Control & $\mathbf{N}$ & $\overline{\boldsymbol{X}}$ & SD \\
\hline Prates & 25 & 67.72 & 7.102 \\
\hline Pascates & 25 & 71.40 & 5.618 \\
\hline \multicolumn{4}{|c|}{$S_{\mathrm{gab}}: 6.403$} \\
\hline \multicolumn{4}{|c|}{$t_{\text {hitung }}: 3.138$} \\
\hline \multicolumn{4}{|c|}{$\begin{array}{l}\mathrm{t}_{\text {tabel }}: 2.021\left(\text { dengan df: } \mathrm{n}_{1}+\mathrm{n}_{2-}\right. \\
2=48 \text { dan } \alpha: 0.05)\end{array}$} \\
\hline
\end{tabular}

Dari tabel di atas dapat dilihat bahwa nilai $t_{\text {hitung }}$ lebih besar dari $t_{\text {tabel }}$ ( $t_{\text {hitung }}=3.138>t_{\text {tabel }}=2.021$ ). Ini berarti $\mathrm{H}_{\mathrm{a}}$ (hipotesis alternatif) diterima, yaitu adanya pengaruh metode inkuiri terhadap keterampilan menulis karangan narasi siswa kelas $\mathrm{X}$ SMA Negeri 1 Kecamatan Payakumbuh.

Pengujian hipotesis dilakukan dengan membandingkan nilai dari kedua kelas yang didapat dari nilai pascates. Langkah awal adalah dengan menentukan $\overline{\boldsymbol{X}}$ dan SD dari tiap kelas, kemudian data tersebut digunakan untuk mencari standar deviasi gabungannya $\left(\mathrm{S}_{\mathrm{gab}}\right)$.Langkah selanjutnya adalah dengan menggunakan data tersebut untuk mencari thitung dengan rumus uji $\mathrm{t}$ ( $t$-tes).Langkah terakhir adalah dengan membandingkan nilai thitung dengan $t_{\text {tabel. }}$. Hasilnya adalah sebagai berikut:

\section{Tabel 8. Hasil Perhitungan Uji t}

\begin{tabular}{|l|c|c|c|}
\hline \multicolumn{1}{|c|}{ Kelas } & $\mathbf{n}$ & $\overline{\boldsymbol{X}}$ & SD \\
\hline $\begin{array}{l}\text { Eksper } \\
\text { imen }\end{array}$ & 25 & 82.60 & 10.00 \\
\hline Kontrol & 25 & 71.40 & 10.72 \\
\hline $\mathrm{S}_{\text {gab }}: 10.3577$ \\
\hline $\mathrm{t}_{\text {hitung } \quad: 3.82092}$ \\
\hline $\begin{array}{l}\mathrm{t}_{\text {tabel }}: 2.021 \text { (dengan df: } \mathrm{n}_{1}+\mathrm{n}_{2-} \\
\text { 2=48 dan } \alpha: 0.05)\end{array}$ \\
\hline
\end{tabular}

Dari tabel di atas dapat dilihat bahwa nilai thitung lebih besar dari $t_{\text {tabel }}$ 
( $\mathrm{t}_{\text {hitung }}=3.82092>\mathrm{t}_{\text {tabel }}=2.021$ ). Ini berarti $\mathrm{H}_{\mathrm{a}}$ (hipotesis alternatif) diterima, yaitu adanya perbedaan yang signifikan antara kemampuan menulis karangan narasi yang diajar dengan metode drill dibanding dengan siswa yang diajar dengan metode konvensional.

Hasil penelitian menunjukkan bahwa adanya perbedaan kemampuan antara siswa yang diajar dengan metode drill dengan siswa yang diajar dengan metode konvensional. Dengan kata lain metode drill lebih efektif dibanding metode konvensional.

Menurut Roestiyah (2008:125) pengertian metode drill adalah suatu teknik yang dapat diartikan sebagai suatu cara mengajar dimana siswa melakukan kegiatan-kegiatan latihan, agar siswa memiliki ketangkasan atau Keterampilan yang lebih tinggi dari apa yang telah dipelajari. Sedangkan menurut Sudjana (2009:86) metode drill pada umumnya digunakan untuk memperoleh suatu ketangkasan atau Keterampilan dari apa yang telah dipelajari.

Menurut KBBI

(2003:592)

Konvensional adalah tradisional. Jadi yang dimaksud metode konvensional adalah metode dalam proses belajar mengajar yang menerapkan cara-cara terdahulu. Guru bertindak sebagai penyampai materi dan siswa hanya sebagai objek dalam pembelajaran. Menurut Djamarah (1996), metode konvensional adalah metode pembelajaran tradisional atau disebut juga dengan metode ceramah.

Hal ini dibuktikan dengan diterimanya Ha (Hipotesis Alternatif), yaitu adanya perbedaan yang signifikan antara kemampuan menulis karangan narasi siswa yang diajar dengan metode drill dibanding dengan siswa yang diajar dengan metode konvensional.

\section{Pengaruh metode drillterhadap} keterampilan menulis karangan narasi siswa kelas X SMA Negri 1 Kecamatan Payakumbuh

Berdasarkan hasil analisis yang telah dilakukan, bahwa pembelajaran menulis karangan narasi dengan metode drill berpengaruh terhadap nilai siswa. Hal ini dibuktikan dengan adanya peningkatan nilai siswa, yang mana pada waktu prates total nilai $(\Sigma) 1704$ dangan nilai ratarata/mean $(\bar{X})$ adalah 68.16 . setelah diterapkan metode drill dalam proses pembelajaran menulis karangan narasi maka nilai siswa mengalami peningkatan pada waktu pascates dengan total nilai $(\Sigma)$ 2065 dan nilai rata-rata /mean $(\bar{X}) \quad 82.60$. Ternyata metode drill sesuai digunakan dalam pembelajaran keterampilan menulis karangan narasi siswa dalam metode drill dapat bertukar pikiran dan dapat menemukan ide-ide baru dalam menulis, karena sering melakukan latihan. Sehingga mereka mampu memperoleh hasil yang baik dalam menulis.

\section{Pengaruh metode konvensional dalam keterampilan menulis karangan narasi siswa kelas X SMA Negeri 1 Kecamatan Payakumbuh}

Berdasarkan hasil analisis yang telah dilakukan, bahwa pelajaran menulis karangan narasi dengan metode konvensional berpengaruh terhadap nilai siswa. Hal ini dibuktikan dengan adanya peningkatan nilai siswa, yang mana pada waktu prates total nilai $(\Sigma) 1693$ dangan nilai rata-rata/mean $(\bar{X})$ adalah 67.72 . Setelah diterapkan metode konvensional dalam proses pelajaran menulis karangan narasi maka nilai siswa mengalami peningkatan pada waktu pascates dengan total nilai $(\Sigma) 1785$ dan nilai rata-rata /mean

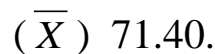

Pembelajaran dengan metode konvensional dalam pengajaran keterampilan menulis memang mengalami kenaikan, tetapi kenaikan nilainya tidak 
Sri Mures Walef: Pengaruh Penggunaan Metode Drill Terhadap Keterampilan

Menulis Karangan Narasi Siswa kelas X SMA N 1 Kecamatan Payakumbuh

Website : https://jurnal.umj.ac.id/index.php/penaliterasiEmail : penaliterasi@umj.ac.id

terlalu tinggi. Jadi, berdasarkan pemerolehan data di atas dapat disimpulkan metode konvensional kurang sesuai diterapkan pada pengajaran keterampilan menulis karangan narasi.

3. Perbedaan yang signifikan antara hasil

Keterampilan menulis karangan narasi dengan metode drill dan metode konvensional

Berdasarkan hasil analisis perbandingan hasil keterampilan menulis karangan narasi siswa kelas X SMA Negeri 1 Kecamatan Payakumbuh antara metode drill dan metode konvensional dapat dilihat dari rata-rata kelas eksperimen (drill) 82.60 lebih besar dibandingkan dengan kelas kontrol (konvensional) 71.40. Hal ini menunjukkan perbedaan yang signifikan antara hasil kemampuan menulis karangan narasi siswa dengan metode drill dibanding penggunaan metode konvensional. Dapat disimpulkan bahwa dalam penelitian ini penggunaan metode drill lebih efektif daripada penggunaan metode konvensional.

Selain perhitungan statistik yang membuktikan bahwa metode drill lebih baik dibandingkan dengan metode konvensional pada hasil menulis karangan narasi siswa, hasil observasi juga menunjukkan hal yang serupa, yaitu dalam proses penerapan metode drill siswa terlihat lebih aktif dari pada metode konvensional.

\section{KESIMPULAN}

$\mathrm{K}^{\prime}$

e Dari hasil penelitian dapat disimpulkan bahwa metode drill berpengaruh dalam keterampilan menulis karangan narasi di kelas eksperimen. Hal ini dibuktikan adanya peningkatan nilai siswa, yang mana pada waktu tes awal nilai ratarata/mean $(\bar{X})$ adalah 68.16 . Setelah diterapkan metode $d r i l l$ dalam proses belajar di kelas eksperimen diperoleh peningkatan hasil pembelajaran siswa pada waktu tes akhir dengan nilai ratarata $(\bar{X})$ 82.60, dengan uji $\mathrm{t}$ (t-test) membuktikan thitung dengan $t_{\text {tabel }}$ (2.251>2,012), karena thitung lebih besar dari $t_{\text {tabel }}$ maka $\mathrm{H}_{\mathrm{a}}$ (hipotesis alternatif) diterima. Jadi, hasil pembelajaran siswa di kelas eksperimen yang diberi perlakuan dengan metode drill berpengaruh dengan sebelum diberi perlakuan.

2. Berdasarkan hasil penelitian, pembelajaran konvensional berpengaruh dalam pembelajaran keterampilan menulis karangan narasi siswa di kelas kontrol. Hal ini dibuktikan dengan adanya peningkatan nilai siswa. Pada tes awal diperoleh rata-rata/mean $(\bar{X})$ adalah 67.72 . Setelah diterapkan pembelajaran konvensional dalam proses belajar di kelas kontrol, didapat peningkatan hasil pembelajaran siswa pada waktu tes akhir dengan nilai rata-rata $(\bar{X}) 71,40$, dengan uji $\mathrm{t}\left(\mathrm{t}\right.$-test) membuktikan $\mathrm{t}_{\text {hitung }}$ dengan $t_{\text {tabel }} \quad(3.138>2.012)$, karena thitung lebih besar dari tabel maka $\mathrm{H}_{\mathrm{a}}$ (hipotesis alternatif) diterima. Jadi, hasil pembelajaran siswa di kelas kontrol yang diberi perlakuan dengan pembelajaran konvensional berpengaruh dengan sebelum diberi perlakuan.

3. Hasil uji t diketahui bahwa adanya perbedaan yang signifikan antara hasil keterampilan menulis karangan narasi antara metode drill dengan metode konvensional. Hal ini nampak pada hasil perbandingan $t_{\text {hitung }}$ dengan $t_{\text {tabel }}$ $(3,820>2.012)$, karena $t_{\text {hitung }}$ lebih besar 
dari tabel maka $\mathrm{H}_{\mathrm{a}}$ (hipotesis alternatif) diterima. Jadi, hasil pembelajaran siswa di kelas eksperimen yang diberi perlakuan dengan pembelajaran drill lebih baik dibanding dengan hasil pembelajaran siswa di kelas kontrol yang diberi perlakuan dengan pembelajaran konvensional.

\section{REFERENSI}

Arikunto, Suharsimi. 2006. Prosedur Penelitian Suatu Pendekatan Praktik. Jakarta: PT Rineka Cipta.

Nurudin. 2007. Dasar-dasar Penulisan. Malang: UMM Press.

Roestiyah. 2008. Strategi Belajar Mengajar. Jakarta: Rineka Cipta.

Semi, Atar. 2008. Dasar-dasar keterampilan menulis. Bandung: Angkasa.

Sudjana, Nana. 2009. Dasar-dasar Proses Belajar Mengajar. Bandung: Sinar Baru.

Yusuf, Muri. 2008. Metode Penelitian Kualitatif Kuantitatif Dan Gabungan. Padang: Prenada Media Grup 